\title{
Pollen Grains in Lake Sediments: Pollen Percentages in Surface Sediments from Southern Michigan ${ }^{1}$
}

\author{
M. B. Davis, ${ }^{2}$ L. B. Brubaker, ${ }^{2}$ And J. M. Beiswenger ${ }^{2}$ \\ Received July 28, 1971
}

\begin{abstract}
Pollen in surface sediments from five lakes in southern Michigan shows evidence of differential deposition. In most lakes, pollen from ragweed occurs in a higher ratio to tree pollen in shallow-water sediment than in deep water. Pine and certain herbs with small pollen grains follow the same pattern. One very deep lake is an exception, with the ratio of ragweed to tree pollen highest in deep-water sediment. Pollen from local aquatics and from willow, which grows along the lake shore, is also unevenly distributed, occurring in highest frequencies near the parent plants. Pollen from deciduous trees, however, occurs in similar ratios at all sampling stations within each lake. Deciduous pollen occurs in uniform ratios, also in older sediment, deposited in the early 19th century, when the landscape was still forested.

Percentages of deciduous tree pollen (as percent tree pollen) were compared among lakes. Single samples were taken for this purpose from the deepest part of each lake basin. Oak pollen percentages are higher in three lakes in western Washtenaw County than in three lakes in eastern Washtenaw County. This difference reflects a similar difference in present-day vegetation: second-growth oak forests grow near the lakes in the western half of the county, while all but $5 \%$ of the area in the eastern part of the county is farmland. (The difference in the ratio of farmland to forestland in the two parts of the county is not reflected clearly in the ratio of herb pollen to tree pollen, because there is so much variation within each lake.) In 140-year-old sediment, on the other hand, tree pollen percentages in the six samples are homogeneous as shown by a chi-square test. The homogeneity in sediment deposited before the forest was cleared is surprising, because witness-tree data from presettlement time show that the frequencies of tree species in the two areas were quite different. Pollen dispersal at that time must have been effective enough, to counteract differences over distances of a few tens of kilometers in the amounts and kinds of pollen produced by the vegetation.
\end{abstract}

\section{INTRODUCTION}

Fossil pollen grains are useful to paleoecology because they record ancient vegetation. The pollen accumulating in lake sediment has its source in vegetation surrounding the lake; as a consequence the quantities of pollen must be related ulti-

\footnotetext{
${ }^{1}$ Contribution number 141 from the Great Lakes Research Division, University of Michigan.

2 Great Lakes Research Division, University of Michigan, Ann Arbor, Michigan 48104.
}

mately to the quantities of parent plants. Pollen has been important in paleoecology primarily because of its potential for providing quantitative information. Often, however, the quantitative reflection of vegetation provided by pollen grains is distorted and difficult to decipher. The distortion can be caused by differential pollen production, differential transport in air, and differential resistance to decay (Faegri and Tversen, 1964). Another factor, seldom discussed in the literature, is differential sedimentation of 
pollen in lake water. Differential sedimentation forms the subject of this paper.

Differential sedimentation means that one type of pollen will be deposited in preference to others in certain parts of a lake. The ratio between this particular kind of pollen and others in the total assemblage will be distorted by this process. The distortion will be different in different kinds of sediment. The differences will confuse interpretation, when fossil pollen from one sediment facies is compared with fossil pollen from another. In studies of modern pollen assemblages the effect will be an increase in variability, or "noise," in samples collected from different sedimentary situations. The noise may mask important differences in pollen assemblages that otherwise could be used to distinguish between different kinds of vegetation.

Recently attempts have been made to measure variability by comparing large suites of samples collected within lake basins. Data by R. B. Davis et al. (1969) and other authors, primarily Kabaliene (1970), implicate sedimentary processes as the source of observed within-lake variations in the pollen content of sediments. The patterns of distribution of pollen frequencies they observed were related to water depth, implying that limnological processes were responsible for the patterns of deposition. The deposition patterns we found involve different kinds of pollen and differ from their results in some respects, because of differences in the geographical region and method of study. But we have come to the same conclusion, that variations in pollen frequencies are correlated with water depth, and are caused by limnological factors that bring about differential deposition of pollen grains. They are caused by processes internal to the lakes and independent of local patterns of terrestrial vegetation.

The sets of samples we studied were collected within seven lake basins, most of them in Washtenaw County, in southern Michigan. Most samples were from the sedi- ment surface, collected systematically along transects to include all sedimentary situations. At a number of stations pollen was also studied in sediment deposited 140 years ago, just before the forest was cleared from the region for farming.

Our results show large differences in pollen assemblages within each of the lakes. The differences follow systematic patterns, repeatable to a large extent from lake to lake. Further studies, to be reported in later papers (M. B. Davis, in press; Davis and Brubaker, unpublished) have revealed that the differences we observed result from preferential sedimentation of small pollen grains (and conifer grains with air sacs) in shallow water, leading to higher ratios with respect to the rest of the pollen flora in sediment there. The remaining large pollen grains (without air sacs) display uniform input to sediment everywhere in the lake basins. The assemblages of these types are very nearly homogeneous in all parts of each of the lakes studied. Redeposition of sediment moves the sediment and its enclosed pollen some months after initial sedimentation, redistributing the sediment and pollen and determining the final rates of absolute accumulation in different parts of the basin.

The variations in pollen assemblages we observed in Michigan lakes have important implications for studies of pollen in fossil sediment. The changes in pollen through time in fossil series can be evaluated only by comparing them with the differences we find now from lake to lake. Irregularly deposited pollen types display high within-lake and between-lake variance: they cannot be interpreted with precision in the fossil record. But uniformly deposited types-the large grains which happen to include most of the deciduous tree species in southern Michigan - can be compared usefully from lake to lake. Because there is so little background variance, they are sensitive to differences in input from the vegetation, revealing the ex- 
tent to which small differences in vegetation on the landscape can be reflected by pollen assemblages in lakes.

\section{DESCRIPTION AND RECENT HISTORY OF STUDY AREA}

The study area, Washtenaw County, Michigan, is in a region of low-relief and gently rolling glaciated topography. Ninety to ninety-five percent of the landscape is now under cultivation as farmland. Before the initiation of farming 140 years ago, however, the area supported deciduous forests. A quantitative sample of the species composition of this forest was provided by the early land surveys (1819-1825), which record witness trees at each quarter-section corner and at points along section boundaries. At that time white and black oak (Quercus alba and $Q$. velutina) were the most common species, making up almost $60 \%$ of all forest trees in Washtenaw County. In the northwestern part of the county, where three of the lakes studied are located, the forests growing on the sandy upland soils were composed almost exclusively of oak ( $85 \%$ of trees recorded) and hickory (Carya, 6\%) (Fig. 1). Oaks were also common $(47 \%) 35 \mathrm{~km}$ to the east, near Frains and Murray Lakes. But on these clay-rich soils in the eastern part of the county the forests were more diverse, with elm (Ulmus), beech (Fagus), ash (Fraxinus), maple (Acer), aspen (Populus), ironwood (Ostrya) and basswood (Tilia) each con-

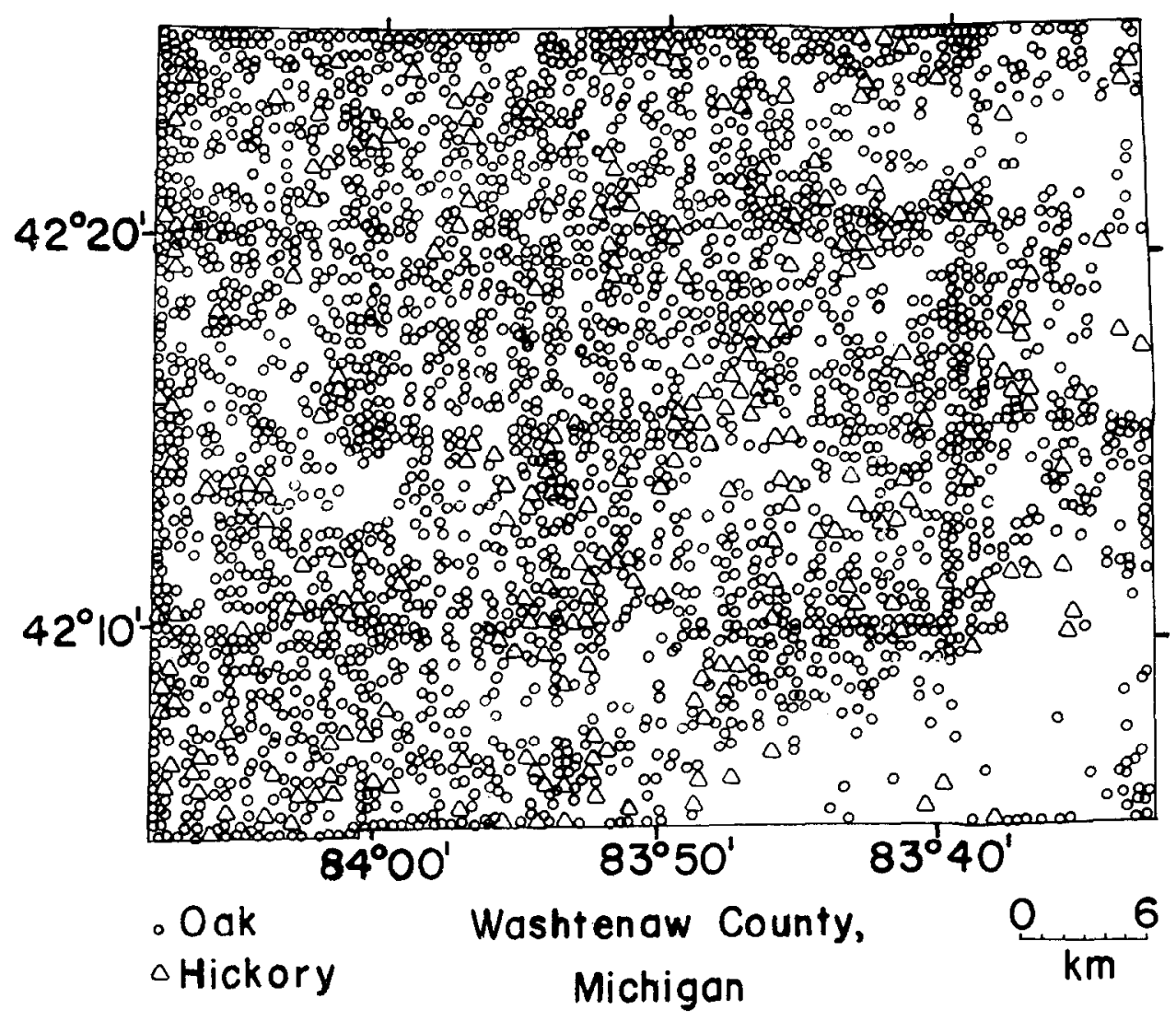

Fig. 1. Locations of oak and hickory trees recorded in the course of the land survey in the early 19th century (after Merk, 1951) (compare Fig. 2). 
tributing 4-9\% of the forest (Fig. 2) (Merk, 1951). Note that pine (Pinus) is not shown on the maps; it is almost completely absent from the forests of southern Michigan.

Farmers settling in the region clear-cut the species-rich forests near Frains and Murray Lakes, starting around 1830 (Anonymous, 1881). The cleared land has been farmed and pastured continuously ever since. Remnants of the original forest, and second-growth forests, occur today as scattered woodlots, totaling about $5 \%$ of the area in eastern Washtenaw County (United States Geological Survey 1:250,000 map, Detroit Sheet).

Five or ten years after deforestation in eastern Washtenaw County, the forests in the northwest, near Blind, Pickerel and Sayles Lakes (Fig. 2) were cleared for farmland. The soils there are sandy, and these farms were less successful than those

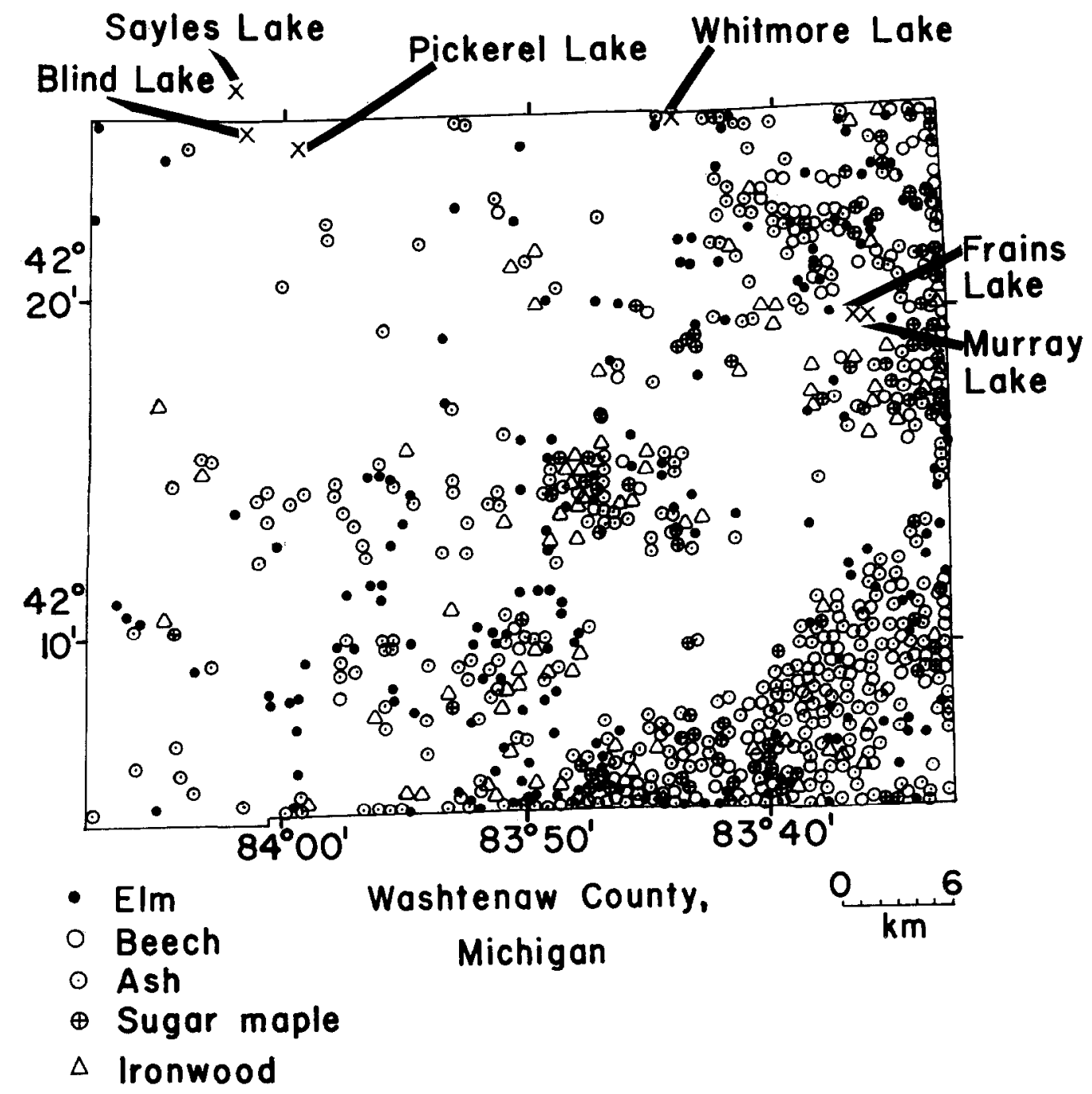

FIG. 2. Elm, beech, ash, sugar maple and ironwood trees recorded in the course of the land survey in the early 19th century (after Merk, 1951) (compare Fig. 1). The locations of six lakes included in the present study are indicated. 
to the east. Many were abandoned early in this century. As a result second-growth oak forests are common in the region (about $9 \%$ of the area of the western half of the county, according to USGS 1:250,000 map, Detroit and Grand Rapids Sheets). Forests now surround the shores of Blind, Pickerel, and Sayles Lakes.

Our most intensive studies were done at Frains Lake, a small (6.6 ha) lake near Ann Arbor. The lake has a single, symmetrical basin, $9.5 \mathrm{~m}$ deep in the center. Water enters the basin as runoff from the surrounding gentle, grass covered slopes. Water may also enter the lake through a marshy area connecting with nearby Murray Lake. At times of high water in the springtime, water overflows northward through a shallow ditch. At other times of year there is no outflow. A few willow (Salix) trees border the north shore of the lake, but around most of the shore there is only a narrow border of shrubs with grassy meadows behind them (Fig. 3).

Several lakes were studied for comparison. The locations of all but one are indicated in Fig. 2 ; their important characteristics are summarized in Table 1. Surface sediments were collected along transects across Frains (Fig. 4), Blind (Fig. 5), Sayles, Pickerel and Murray Lakes, and in the deepest part of Sodon and Whitmore Lakes.

\section{METHODS}

The samples used for surface sediment study were cores through the mud-water interface, collected in plastic tubes with a piston sampler (Rowley and Dahl, 1956), or with a modified free-fall valve corer (Phleger, 1951). The latter uses a plastic tube held within a weighted brass tube equipped with a check valve at the upper end. The sampler is lowered into the water on a rope and allowed to fall the last $6 \mathrm{ft}$. into the sediment. Cores were frozen in their plastic tubes in a upright position to prevent mixing of the sediment. Later they were extruded from the tubes and chopped into segments, each of which was analyzed separately. The uppermost $2 \mathrm{~cm}$ of sediment is considered the "surface sample." The sedimentation rates in these lakes average 2-3 mm per year (M. B. Davis, Brubaker and Beiswinger, unpublished data) ; surface samples represent accumulation during the last 10 years, approximately. At Blind and Pickerel Lakes the upper $5 \mathrm{~cm}$ was used. Here the sedimentation rate is slower (1-2 $\mathrm{mm}$ ) and the samples represent sediment deposited over several decades. In all cases it can be assumed that burrowing organisms have mixed the sediment to a greater or lesser degree with older material (Davis, 1967).

Chemical treatment of samples used for pollen analysis included $\mathrm{HF}$, treatment for 6 min. with hot $10 \% \mathrm{KOH}$, and acetolysis for 1 min. (Faegri and Iversen, 1964). Marly sediment was treated with $10 \% \mathrm{HCl}$ as well. Bromoform flotation was used for a few samples containing coarse sand. The prepared residue was mounted in silicone fluid; counting continued until at least 150 tree pollen grains were tabulated. Counts for all relevant samples are given in Tables $2-6 .^{3}$

\section{PRF.SFTTI.FMFNT SEDIMENT}

A distinctive time horizon can be identified in the cores by pollen analysis. Forest clearance during the 19 th century changed the percentages of pollen produced by the vegetation. Tree pollen declined in frequency, and pollen from ragweed (Ambrosia) and other herbaceous species increased (Fries, 1962; McAndrews, 1966). The horizon is identified easily in sediment from

\footnotetext{
3 For Tables 2, 3, 4, 5 and 6, order NAPS Document 01679 from ASIS National Auxiliary Publications Service, \% CCM Information Sciences, Inc., $22 \mathrm{~W}$. 34th Street, New York, New York, 10001, remitting $\$ 2.00$ for microfiche or $\$ 5.00$ for photocopies.
} 


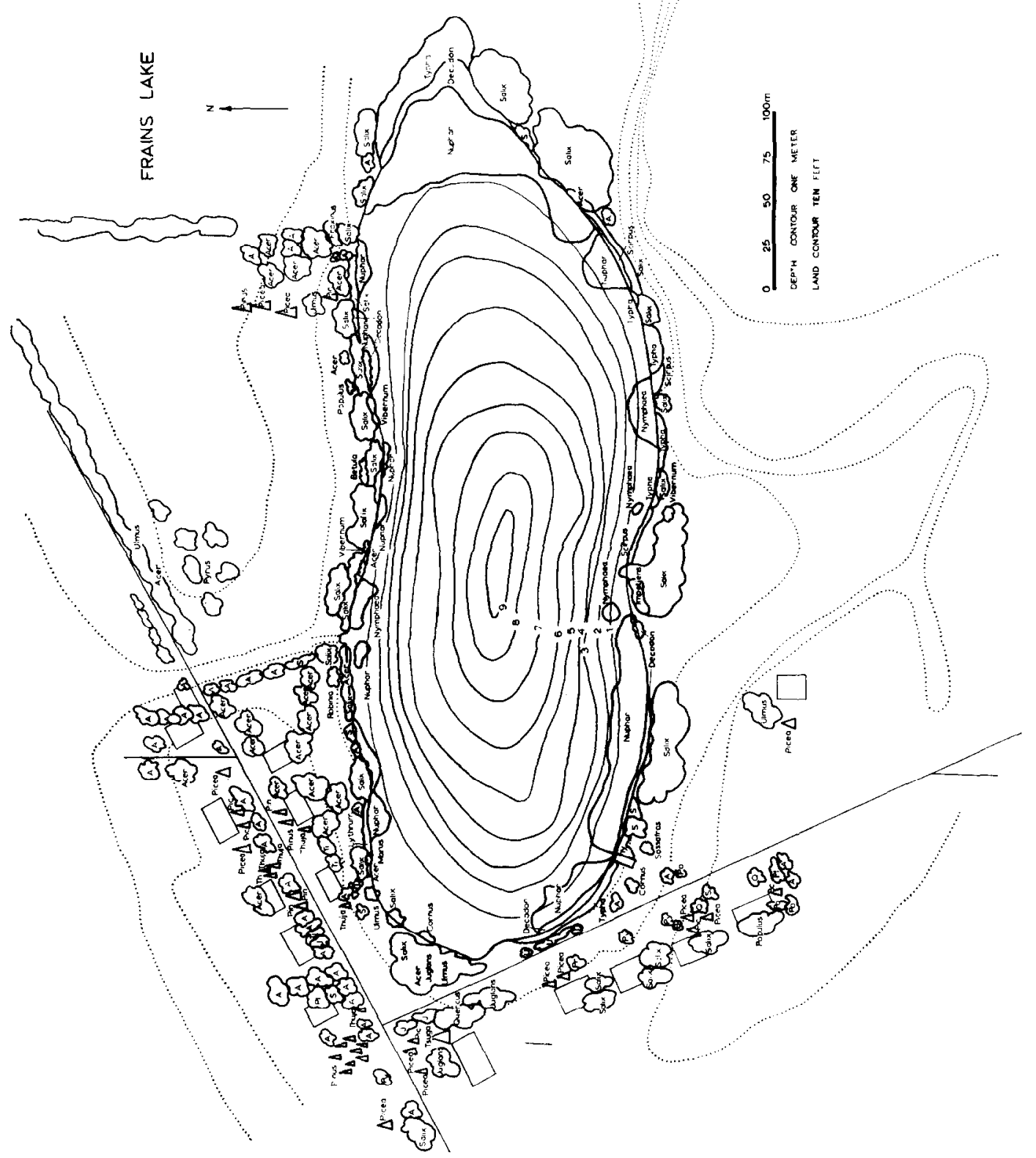

FIG. 3. Frains Lake, showing depth contours (in meters) and the areas occupied by trees, shrubs and water plants near the lake. Square and rectangular areas are buildings, the straight lines roads. Land contours (in feet) are shown by dotted lines. The elevation of the lake surface is $820 \mathrm{ft}$ (after USGS $71 / 2$ min. topographic sheet, Denton Quadrangle). Bathymetric map modified from the Michigan Conservation Department map.

southern Michigan (Fig. 6). Ragweed pollen increases from less than $1 \%$ to $15-40 \%$; grass (Gramineae), sorrel (Rumex) and pigweed (Chenopodiaceae) pollen percentages increase. Pollen from oak, beech, ash and several additional tree genera, not shown on the diagram, decrease in percentages. Pollen from maize $(Z e a)$, 
TABLE 1

Morphometric Features of Lakes Studied in Southern Michigan

\begin{tabular}{|c|c|c|c|c|c|c|c|}
\hline $\begin{array}{l}\text { Lake } \\
\text { name }\end{array}$ & County & $\begin{array}{r}\text { Area } \\
\text { (ha) }\end{array}$ & $\begin{array}{l}\text { Maximum } \\
\text { depth } \\
\text { (m) }\end{array}$ & $\begin{array}{l}\text { Num- } \\
\text { ber of } \\
\text { basins }\end{array}$ & $\begin{array}{l}\text { Depth to } \\
\text { thermocline } \\
\text { in summer } \\
\text { (m) }\end{array}$ & $\begin{array}{l}\text { Lake } \\
\text { type }\end{array}$ & $\begin{array}{l}\text { Surrounding } \\
\text { vegetation }\end{array}$ \\
\hline Sayles & Livingston & 6 & 3 & 1 & None & Holomictic & $\begin{array}{c}\text { Forest, some } \\
\text { meadow }\end{array}$ \\
\hline Sodon & Oakland & 2 & 20 & 1 & 7 & Meromictic & $\begin{array}{l}\text { Forest, } \\
\text { houselots }\end{array}$ \\
\hline Murray & Washtenaw & 7 & 12 & 1 & $3-6.5$ & Dimictic & $\begin{array}{l}\text { Forest, } \\
\text { meadow }\end{array}$ \\
\hline Frains & Washtenaw & 6.6 & 10 & 1 & 4 & Dimictic & Meadow \\
\hline Pickerel & Washtenaw & 6.8 & 15.5 & 1 & $5-8$ & Dimictic & Forest \\
\hline Blind & Washtenaw & 25 & 24 & 2 & 6 & $\begin{array}{l}\text { Dimictic or } \\
\text { monomictic }\end{array}$ & Forest \\
\hline Whitmore & Washtenaw & 274 & 21 & 3 & $8-13$ & Dimictic & $\begin{array}{l}\text { Forest, } \\
\text { meadow, } \\
\text { houselots, } \\
\text { resort }\end{array}$ \\
\hline
\end{tabular}

buckwheat (Fagopyrum) and other cultivated plants and from narrow-leaved plantain (Plantago lanceolata), a weed species introduced from Europe, occur at the levels in which ragweed pollen is abundant, and not below, leaving little doubt that the changes do in fact represent the clearance of forest for agriculture. In the diagrams from Blind Lake, in western Washtenaw County (Fig. 6), there is a reversal very near the surface, with oak pollen percentages increasing again, while weed pollen de- clines. This trend records farm abandonment since the early 1900's in the immediate vicinity of the lake. Diagrams from Frains Lake, 20 miles to the east in Washtenaw County, where the landscape has remained under cultivation, show high percentages of ragweed continuing to the surface.

"Presettlement samples," identified in cores by pollen analysis, were used to study pollen deposition in the early 19th century, when the landscape was still forested. In Fig. 6, the samples identified as presettle-

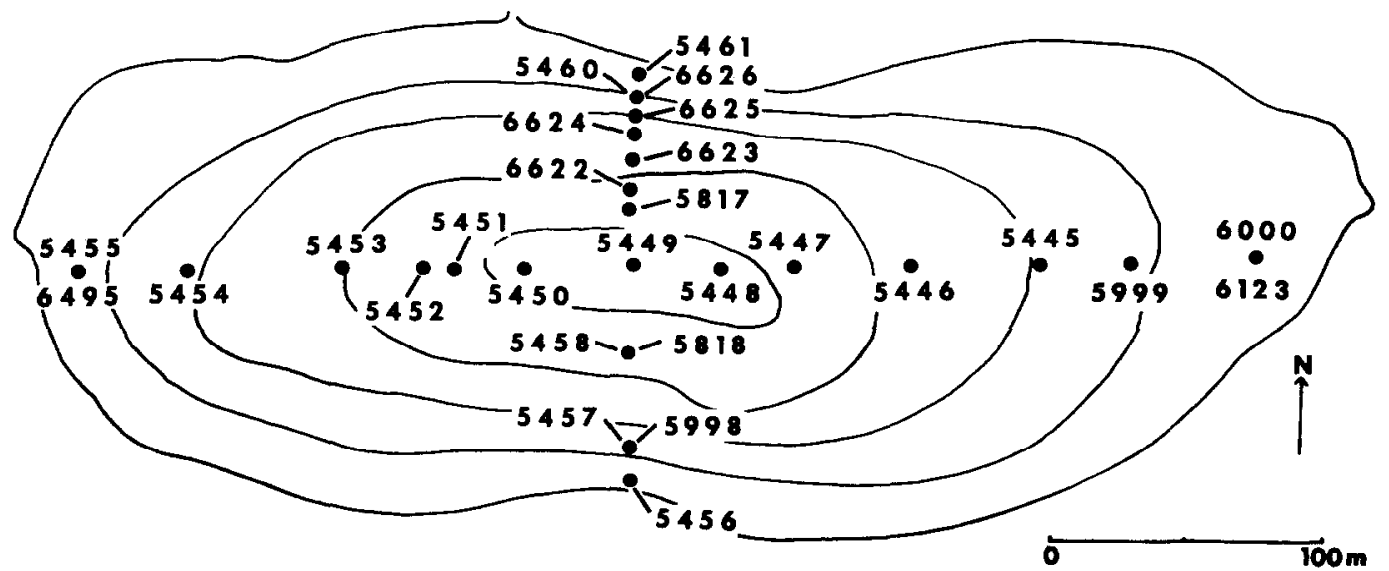

FIG. 4. Sampling locations in Frains Lake. 


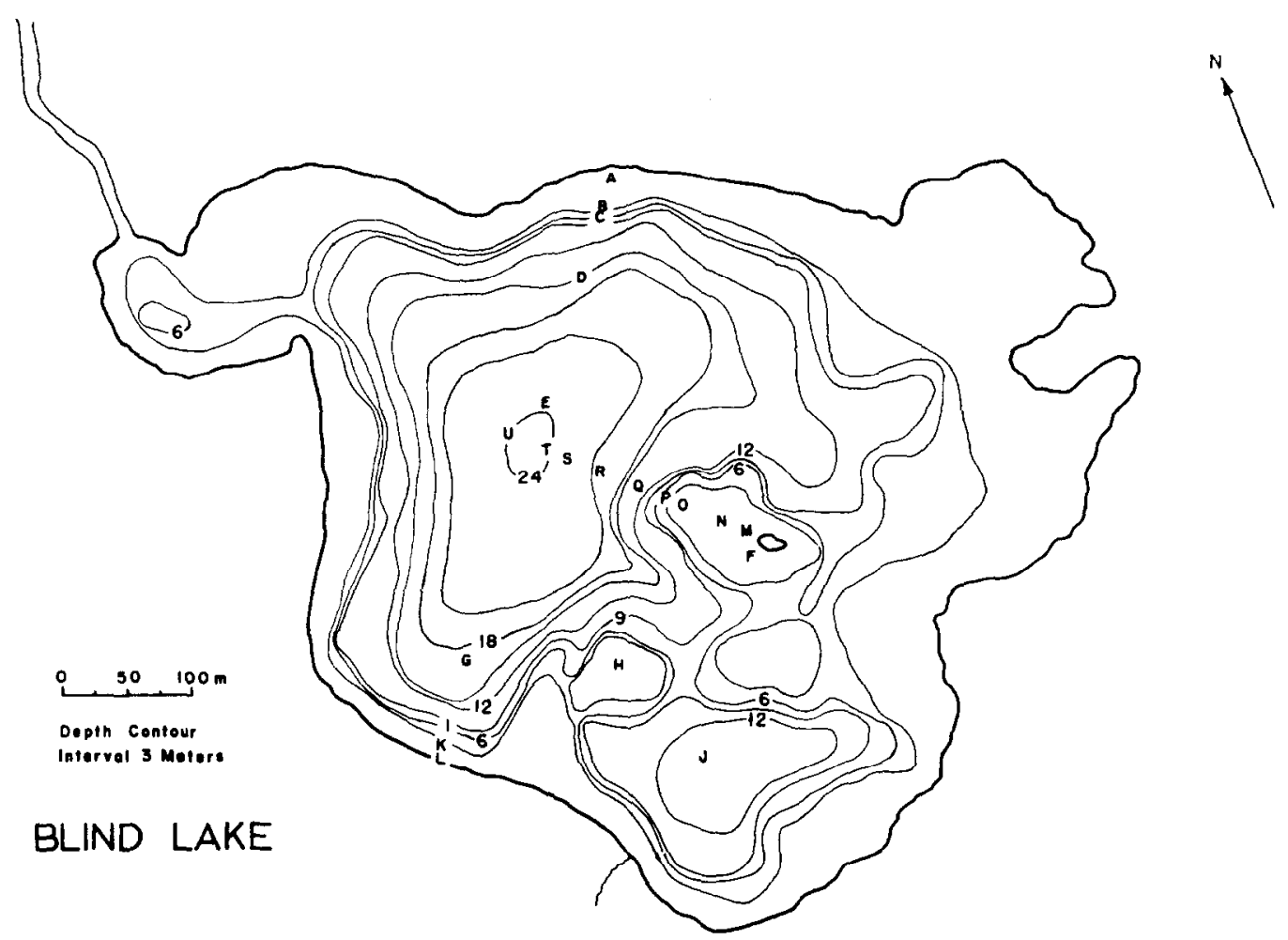

FIG. 5. Bathymetric map of Blind Lake, showing sampling locations.

ment are those immediately underlying the level indicated by the dashed line.

\section{REGIONAL AND LOCAL POLLEN \\ IN FRAINS LAKE}

A useful distinction can be made between local and regional pollen. Local pollen, as we are defining it here, is from plants growing so close to the lake that pollen can fall vertically onto the water surface. (Note: This definition differs slightly from that used by Janssen, 1966.) The input of local pollen to the lake water will be irregular, because the greatest number of grains will fall onto the lake surface near the parent

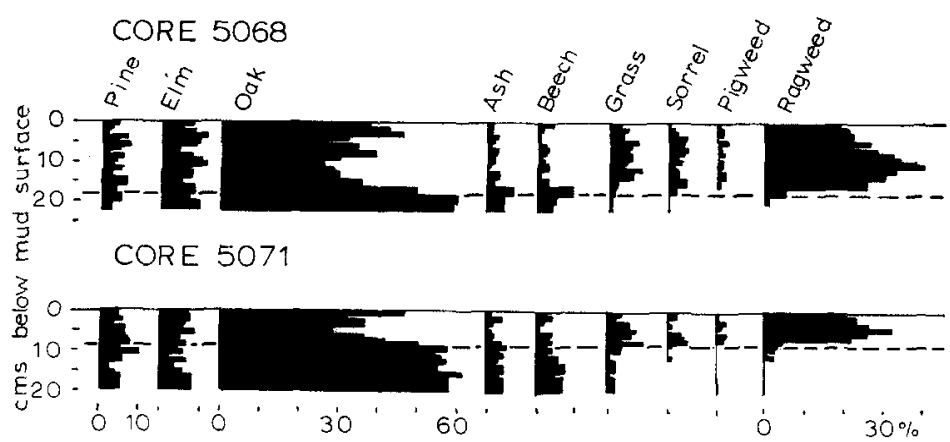

FIG. 6. Pollen diagrams from two short cores from Blind I ake. Perrentages of the major pollen types are plotted against depth in the sediment. The dashed line indicates the settlement horizon (1830 A. D.). Core 5068 is from station $\mathrm{H}$, and core 5071 from station $\mathrm{K}$ in Fig. 5 . 
plants. At Frains Lake a few trees that grow along the shores of the lake are in the local category. The most important is willow; large willow trees ( $S$. nigra and $S . b a$ bylonica) and some willow shrubs grow along the northern and eastern shores (Fig. 3 ). There are also a few maple and poplar trees near the shore, but since these trees are abundant at a greater distance from the lake, it seems likely that only a small porportion of the maple and poplar pollen entering the lake is local in origin. The most abundant local pollen is from aquatic and emergent vegetation. These plants are irregularly distributed in the shallow waters of the lake (Fig. 3), and the pollen they produce will fall onto the water surface in an irregular pattern.

Regional pollen, on the other hand, is carried some distance-several hundred meters or even several kilometers-before it reaches the lake. Consequently we may expect a more or less uniform fallout onto the lake water surface. Oak pollen, for example, makes up between $20 \%$ and $40 \%$ of all the pollen in the lake sediment. Yet only three trees grow near the lake, a large tree and two saplings about $25 \mathrm{~m}$ from the western shore (Fig. 3). These three trees can hardly be the source of the billions of grains (ca. 3 $\left.\times 10^{12}\right)$ (M. B. Davis and Brubaker, unpublished) that enter the lake each year. According to Pohl's (1937) estimate of the pollen productivity of European oaks, 30,000 10-year old branching systems are necessary to produce this many pollen grains each year. The majority of the oak pollen grains must, therefore, come from the oak woodlots and forests that are scattered throughout Washtenaw County. The nearest of these is one-half $\mathrm{km}$ distant from the lake. There is no reason to suppose that oak pollen from these distant sources would fall onto one part of the lake in preference to another.

Much of the herb pollen entering the lake is also regional in origin. The most common type is ragweed. It grows abundantly as a weed in fields and along roadsides and in other areas of broken ground and does not occur in the grassy meadows that surround Frains Lake. Grass and weed pollen can probably be considered regional in origin, too, while sedge (Cyperaceae) pollen must be considered local since some at least may come from sedges growing in the shallow water along the lake margin.

\section{RESULTS_FRAINS LAKE}

The distributions of pollen percentages in the lake sediments fall into three general patterns.

(1) Regional types with little or no variation within the lake. This group includes most tree pollen, except pine, which occurs rarely, and the local types like willow. The ratio of oak to total tree pollen (excluding willow) is almost exactly similar at all 28 sampling stations, in both shallow and deep water (Fig. 7). Presettlement samples are equally invariant. Oak is the only kind of tree pollen that occurs in high frequencythe others, primarily elm, ash, beech, hornbeam and maple, occur in percentages of 5 and $10 \%$. Fig. 8 shows that these percentage values are also similar in samples collected at a variety of depths within the lake. The frequencies of deciduous tree pollen were tested for homogeneity by means of a chi-square test. All deciduous tree pollen except willow at all sampling stations at Frains Lake was inclided in the test. The result $\left(\chi^{2}=269.00, \mathrm{df}=168, p<.001\right)$ demonstrates that the tree pollen frequencies are nonhomogeneous. Oak pollen frequencies appear by subjective judgment to be greater in deep-water samples, while maple and butternut seem more abundant in shallow-water samples. These differences were tested for significance. The means and variances of the frequencies of each deciduous tree pollen type in the 14 shallowwater samples were compared to those in 

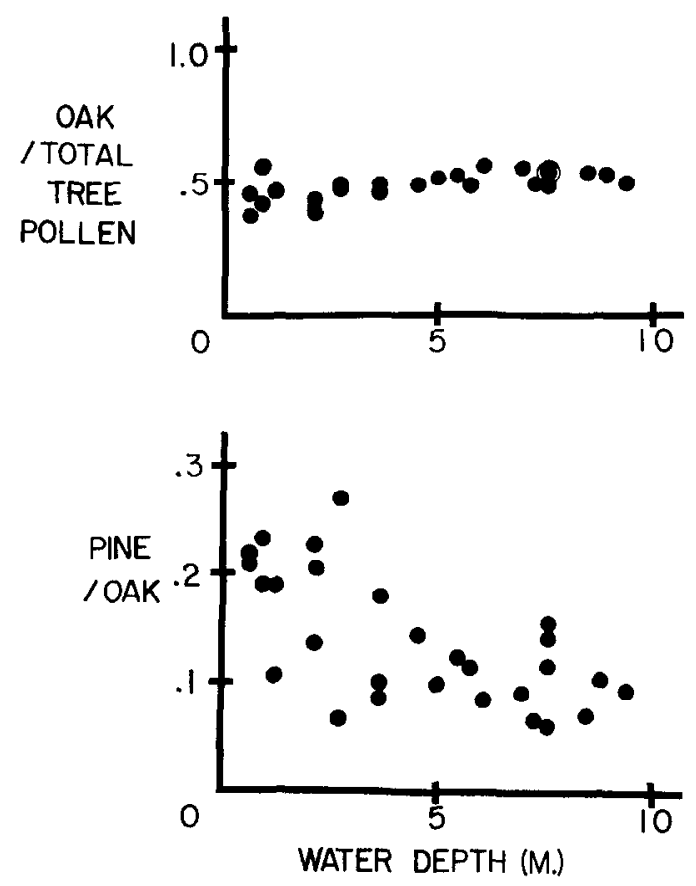

FIG. 7. Pollen ratios in surface samples from Frains Lake, plotted against the water depth at the sampling stations.

the 14 deep-water samples by means of $t$ frequencies of deciduous tree pollen in the tests and $f$ tests, respectively; no significant sediment are not completely homogeneous, differences could be demonstrated. One they show no clear pattern of difference must therefore conclude that although the from water depth in one lake to another.

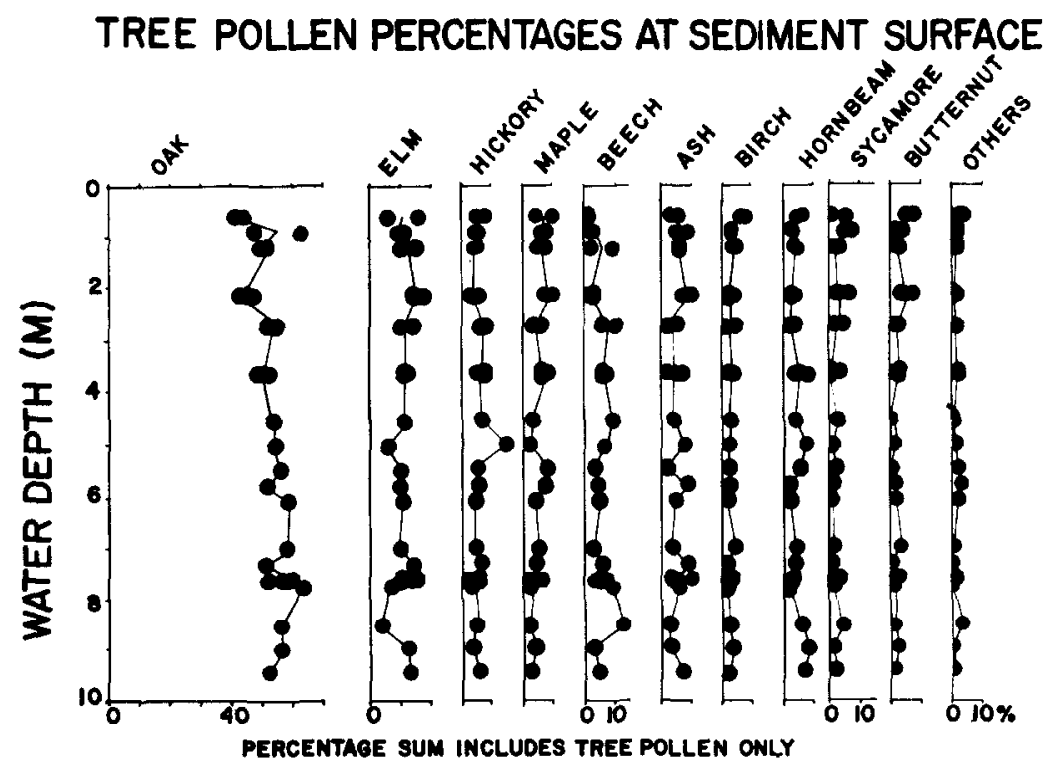

FIG. 8. Pollen percentages for deciduous tree pollen (as percent total deciduous tree pollen) at Frains Lake, plotled against the water depth at the sampling station. 
The pollen counts themselves are given in Tables $2-6$, to which the reader is referred for detailed information.

We find that chi-square is an unsatisfactory measure to use for expressing variability of pollen assemblages. We have used it for lack of a better statistic, but feel called upon to warn the reader of the misleading conclusions that can be drawn from chisquare calculations. One of the drawbacks of chi-square homogeneity tests is that the number of degrees of freedom will depend strongly on the number of grains counted. Each data cell must contain 5 counts; collapsing of categories is necessary where there are fewer. The result is that authors counting 1000 or more grains can use a $x^{2}$ test with many degrees of freedom, demonstrating significant differences between samples. Another author, counting only 250 grains, could use a $\chi^{2}$ test on the same material, in necessity a less sensitive test with fewer degrees of freedom, and show that there are no significant differences among the samples. This is one reason for the seemingly contradictory statements in the literature about the homogeneity of pollen in contemporaneous sediments. In the present instance we have demonstrated inhomogeneities, but we want to emphasize that the deciduous tree pollen frequencies are nevertheless closely similar from one sample to the next.

Because oak pollen is abundant, and shows no significant differences in its frequency relative to total trees from one station to another (Fig. 7), we have found it convenient to use oak pollen as a standard to which other pollen types can be compared. In the following discussion relative pollen frequencies are often expressed as the ratios of individual types to oak pollen. It must be understood, however, that these ratios give no information about the absolute amounts of pollen. We are not assuming that the oak numbers are constant-only that they are a convenient standard for com- parison. To understand the processes affecting pollen deposition, one must know which types are varying independently of others; this can be determined most easily by measuring absolute deposition (M. B. Davis and Brubaker, unpublished). The relative numbers deposited are nevertheless of importance because they are so frequently used in paleoecology.

(2) Regional types that vary within the lake. This group includes pine and all terrestrial herbs. Pine trees are very rare in southern Michigan and the pollen frequency is low- about $2-3 \%$ of total pollen. Nevertheless there is a tendency for the percentages to be higher in shallow water than in deep water (Fig. 7). This corresponds to observations made by others in North America and in Europe (R. B. Davis et al., 1969; Kabaliene, 1970). The ratio of pine to oak pollen, plotted against water depth at the sampling stations, is shown in Fig. 7. There were few pine grains in the samples; counting errors are partly responsible for the wide scatter of points.

Terrestrial herb pollen also occurs in higher percentages in shallow water than in deep water. This effect does not arise from the local distribution of these herbs because they are not abundant near the lake. Ragweed, for example, which contributes about two-thirds of the herb total, occurs in highest percentages in shallow water (Fig. 9). Terrestrial herbs exclusive of ragweed and sedge (which is local) are also shown in Fig. 9. The ratio of grass pollen to oak pollen (Fig. 9) also shows highest values in shallow-water samples.

(3) Local pollen types that occur in highest frequency in sediment near the parent plants. The paucity of local vegetation in Frains Lake makes this a small group, including only willow pollen from the shrubs and trees that grow along the shore, and pollen from aquatic and emergent plants that grow in the lake itself. Figure 10 shows the willow: oak ratio plotted on a map of 

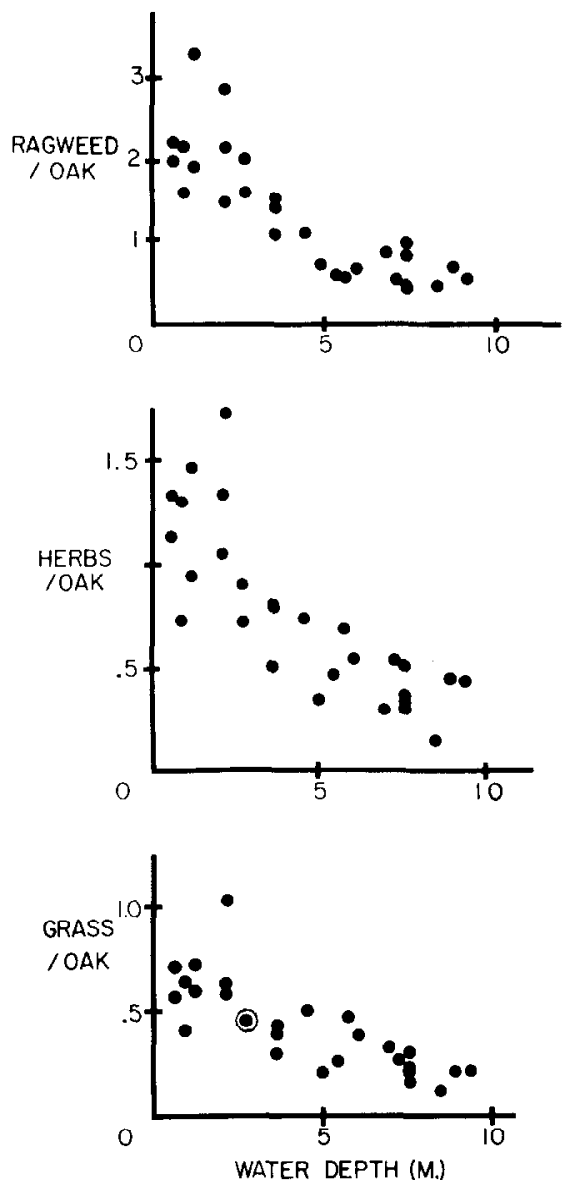

Fig. 9. Pollen ratios in surface samples from Frains Lake, plotted against the water depth at the sampling stations. "Herbs" refers to total terrestrial herbs less ragweed and Cyperaceae.

Frains Lake. The ratio varied from 0.79 (the largest circles) to 0.15 (the smallest circles). The highest willow: oak ratios are found very near the willow trees along the shores, or near to concentrations of willow shrubs at the eastern end of the lake (compare Fig. 3).

The ratio of aquatic plant pollen to oak is highest in water less than $2 \mathrm{~m}$ deep, where rooted aquatic and emergent plants are growing (Fig. 10). The most spectacular example is water-willow (Decodon), which grows prolifically in the swamp at the eastern end of the lake. The high frequency of its pollen in the sediment there (Fig. 10) is quite characteristic, permitting identification of sediment from that end of the lake from its pollen content alone. When the other aquatic and emergent plant genera, principally Potamogeton and Typha, but also including Nymphaea and Nuphar, are considered singly, they show similarly localized distributions (Table 2).

\section{RESULTS-ADDITIONAL LAKES IN SOUTHERN MICHIGAN}

The patterns of variation in pollen frequency found at Frains Lake are repeated, with some important differences, in several lakes in southern Michigan. Since the local vegetation was not mapped at these lakes, we have no information about the distribution patterns of locally produced pollen. Among the regional types (as defined for 

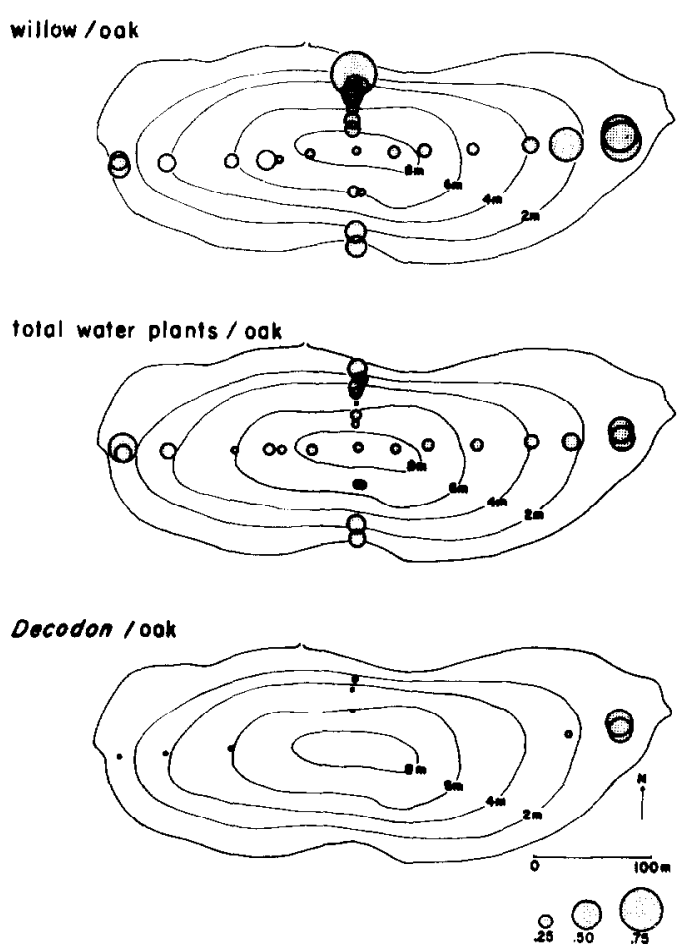

FIG. 10. Pollen ratios in surface samples from Frains Lake, shown at the sampling stations. The area of the circles is proportional to the value of the pollen ratios.

Frains Lake), however, the deciduous tree pollen percentages are nearly uniform at all the lakes we have studied, just as they were at Frains Lake. Figure 11 shows the ratio of oak to total tree pollen (excluding willow) plotted against water depth, in surface samples from five lakes. As at Frains, there is little or no between-station variation, although the value of the ratio is higher at some lakes than others. The ratio of oak pollen to total trees is highest at Blind, Pickerel and Sayles Lakes, located in the northwestern part of the county where oak forests are now more abundant.

The regional pollen types that were variable from one sampling station to another at Frains Lake are also irregularly distributed in all the other lakes. Most lakes show higher frequencies for pine pollen in shallow water. Several of the lakes studied show patterns of distribution of ragweed pollen that are similar to Frains. At Murray Lake and Pickerel Lake, for example, the ratio of ragweed to oak pollen is generally higher in shallow water, and lower in deep-water sediment (Fig. 12). These two lakes are similar in size and morphometry to Frains Lake. But at Sayles Lake, no pattern is apparent. Sayles is very shallow, with water less than $1 \mathrm{~m}$ deep over most of its area. The entire lake is similar to the littoral area of the other lakes we have studied. Pollen ratios were more variable in littoral sediment than in deeper water at Frains Lake (Fig. 9); it is not surprising that similar variation characterizes the entire transect across Sayles. Variability of pollen percentages in sediment collected in shallow water is also reported by R. B. Davis et al. (1969), who used the value of chi-square to measure variation in pollen assemblages from shallowwater and deep-water samples from Wisconsin lakes.

The ragweed: oak ratio at Blind Lake 


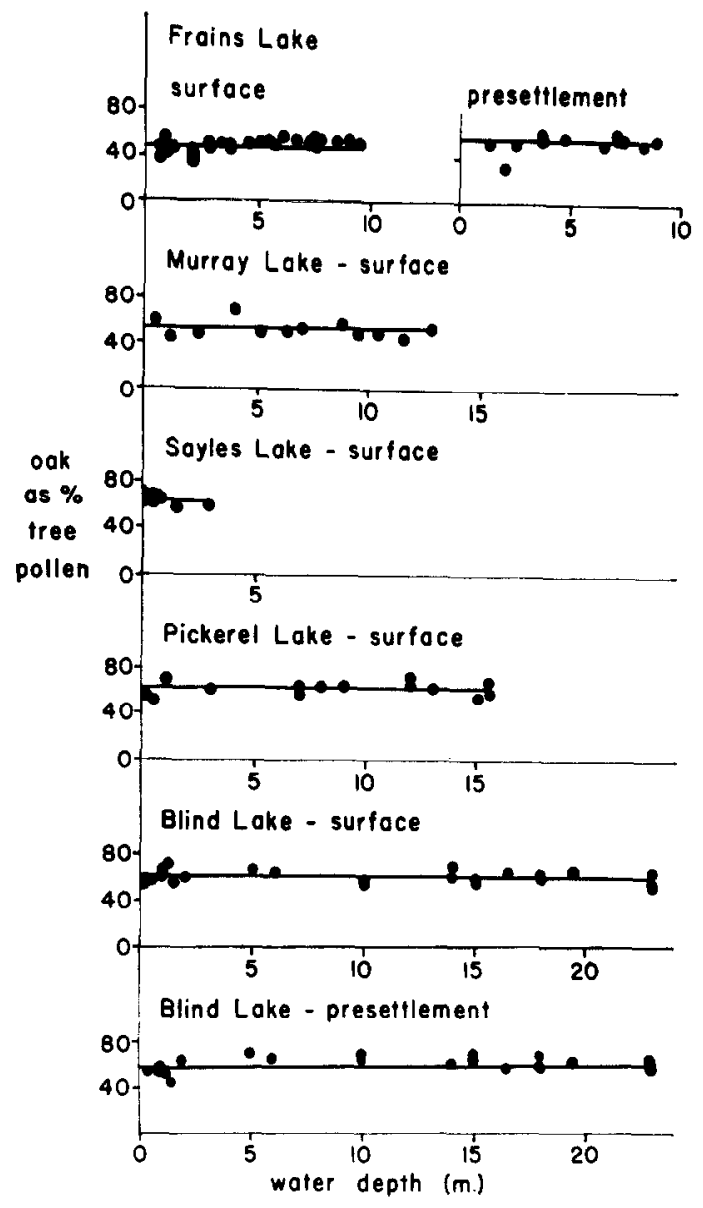

FIG. 11. Pollen ratios (oak to total tree pollen, $\times 100$ ) in five lakes, plotted against the water depth at which the samples were collected. Ratios in presettlement sediment are shown for comparison from the same stations in two of the lakes. Presettlement sediment was identified from its low ragweed and weed pollen content. Straight lines were fitted to the data by eye.

(Fig. 12) is unique among the lakes we studied. In samples from shallow water, the ragweed : oak ratio is lower than in the other nearby lakes. It decreases to a minimum in sediment from water 5-10 $\mathrm{m}$ deep. The ragweed: oak ratio then rises again, to highest levels in the deepest portion of the lake. The presence of a shoal-area near the center of the lake (Fig. 5) has permitted us to test the idea that these variations in ratio are in fact related to water-depth rather than to distance from shore. The shallow-water samples are variable, both near shore and in the lake center. But the low ratio of ragweed: oak that characterizes samples from 5-10 $m$ depth near shore, is repeated at that depth near the center of the lake. The high ragweed: oak ratio was found in both deep basins of the lake. These occurrences imply that water-depth, not distance from shore, is the important variable correlated with this distribution of pollen percentages.

Another interesting datum is the difference in ragweed: oak ratio in deep water in nearby lakes. Many palynologists have thought that a sample or core taken from the deepest part of a lake basin is a "standard" sample. Our study shows that the per- 


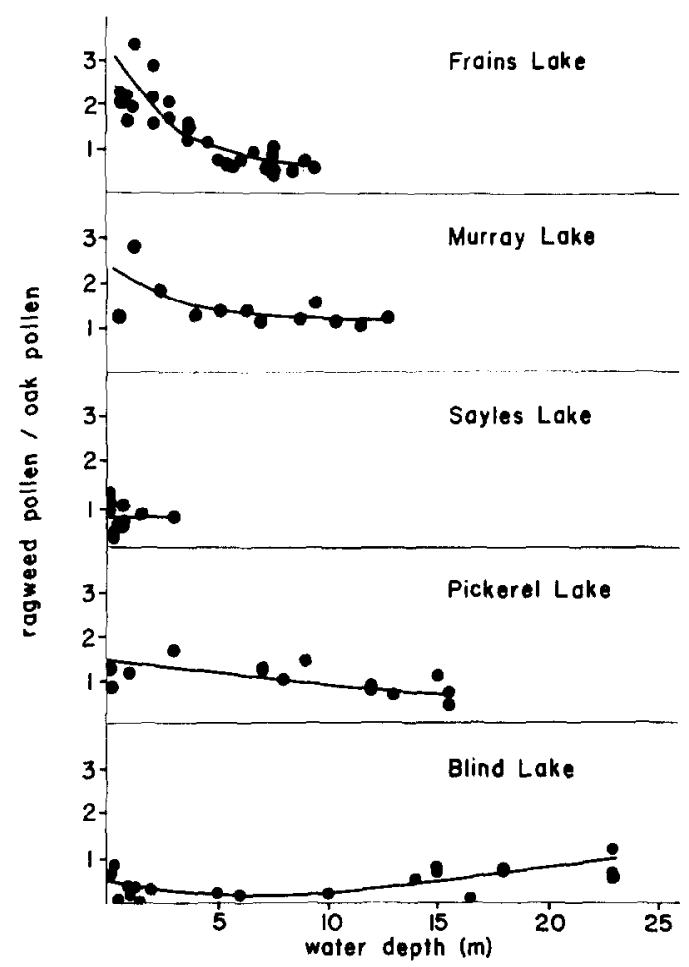

FIG. 12. Pollen ratios in surface samples from five lakes, plotted against the water depths at which the samples were collected. The lines have been fitted to the points by eye.

centage of ragweed in deep water is different, even in adjacent lakes, such as Frains Lake and Murray Lake. These lakes are the same size, but Murray is deeper and shielded from wind by adjacent hills. Oak woodlots grow close to the shores of Murray Lakc, but the percentage of ragweed pollen in deep-water sediment there is higher than at Frains Lake. Data such as these have convinced us that the patterns of distribution of pollen percentages that we are observing are controlled by limnological factors rather than by the distribution of nearby terrestrial vegetation.

\section{IMPLICATIONS OF RESULTS TO PALEOECOLOGY}

\section{A. Local Pollen}

Pollen from local plants does not travel far within the lake. This can be an advantage to the paleoecologist, since high percentages in sediment indicate the nearby oc- currence of the parent plants. High frequencies of willow pollen, for example, indicate that the shore is close to the sampling site, and that willow shrubs or trees are growing along the shore. This could be important information. Tauber (1967) has shown that willow thickets along the shore of a lake filter pollen as it is blown in from the surrounding forest, removing larger grains and thus changing the percentages of pollen entering the lake. At Frains Lake the winds are too strong for shrubs to be effective as filters (Davis, 1968). The pollen diagrams from Frains Lake do, however, show a very recent, postsettlement increase in willow pollen. This effect is strongest in near-shore cores, reflecting the development of a band of willow shrubs after the forest was cleared. Much of the pollen also comes from large weeping-willow trees (Salix babylonica) which were of course planted after the area was settled (Fig. 3 ). 
Many pollen diagrams in the literature show intriguing changes through time in the percentages of aquatic plant pollen. These are often quite different from site to site, as would be expected for locally distributed pollen types. Interpretations can probably be made in great detail. If several cores are studied from within a single basin, for example, changes in aquatic plant pollen might be used to detect changes in the distribution of aquatic and emergent plants, giving information on water transparency and/or water level.

\section{B. Regional Pollen, Variable Types}

Regional pollen types whose percentages are variable in lake sediments give only the crudest quantitative information about the vegetation. The percentages of pine pollen, for example, will vary depending upon the water depth where the sediment sample was collected. Large variations also characterize herb pollen percentages, especially ragweed. Of course, there is some relationship to veg- etation: everywhere in the lakes we studied, the percentage of herbs is higher at the surface than in presettlement sediment, reflecting the increase in open land. The magnitude of the percentage increase, however, fails to give an accurate picture of the magnitude of increase in open land, since there is no single ratio of herb to tree pollen that can be considered typical for any of the lakes, much less characteristic for the landscape in general.

In order to demonstratc this obscrvation, we compared pollen in single samples from seven lakes in southeastern Michigan, including the five Washtenaw County lakes, Sayles Lake in Livingston County, and Sodon Lake in Oakland County (Fig. 2) (Table 1). Each surface sample was from near the center of the deepest basin of the lake. The deepest area was chosen for sampling because pollen assemblages have lower variance in sediments deposited in deep water (Davis et al., 1969). The results (as percent total pollen) are arranged in gcographic order, with the easternmost lake at
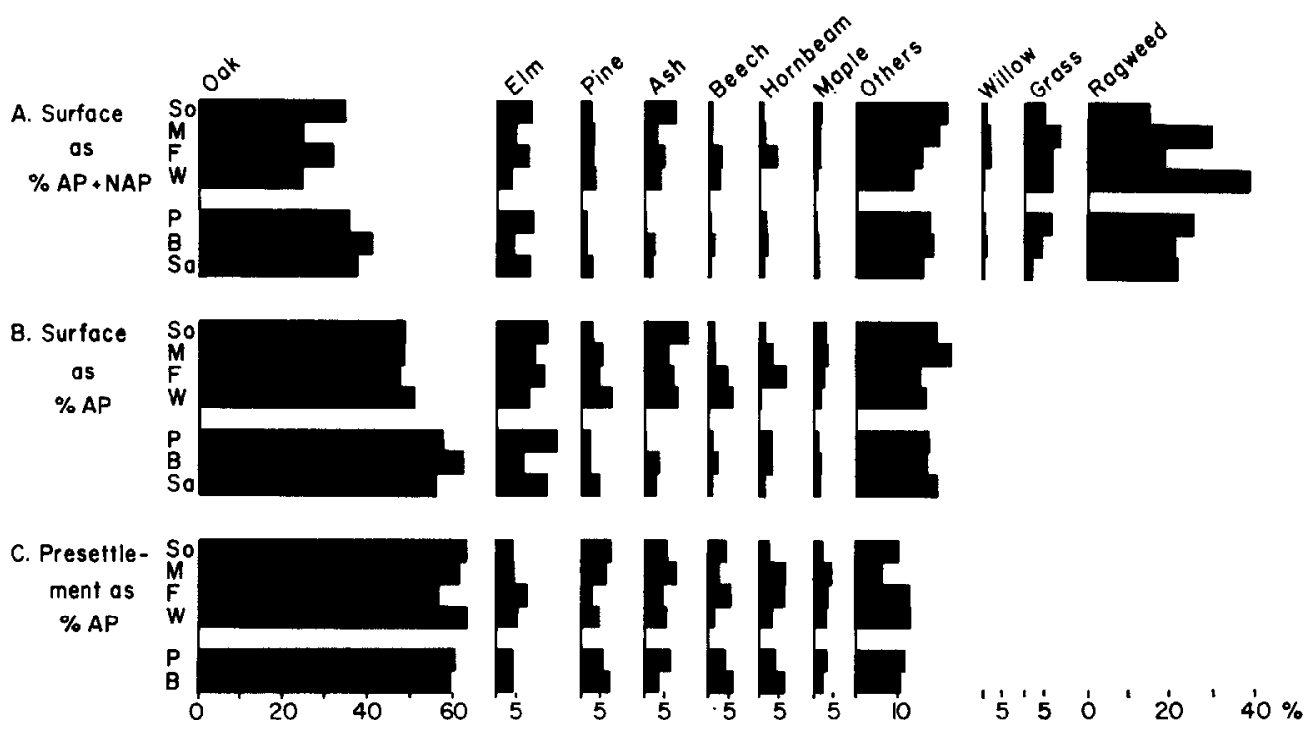

FIG. 13. Pollen percentages in surface and presettlement sediment at seven lakes in southern Michigan. The upper group of lakes in each part of the figure is located to the east of the lower group. Code letters for lakes: So is Sodon Lake, M is Murray Lake, F is Frains Lake, W is Whitmore Lake, $\mathrm{P}$ is Pickerel Lake, $\mathrm{B}$ is Blind Lake, $\mathrm{Sa}$ is Sayles Lake. See Fig. 2 and Table 1 for locations of lakes. 
the top of the figure and the westernmost at the bottom (Fig. 13A). The percentages are highly variable from lake to lake. The variation in the assemblages is caused largely by variations in the quantity of nonarboreal pollen. The resulting noise in the data makes it difficult to detect regional trends in the assemblages. The percentages of tree pollen are much less variable, and a clearer picture emerges when they are considered alone. The reduction in variability can be expressed quantitatively. We calculated chisquare, as for a homogeneity test, using all of the assemblages, and including the counts for nonarboreal pollen. When all pollen types are included the value of $\chi^{2}$ is 407.7 with 35 df ; $p<0.00001$. When nomarboreal pollen is not included (Fig. $13 \mathrm{~B}$ ), $\chi^{2}$ falls to 45.7 with 20 df $p=0.0009$. The higher value of $p$ is a measure of the lesser heterogeneity of the assemblages when tree pollen alone is considered. The vegetational significance of the assemblages will be discussed in the next section.

\section{Regional Pollen, Uniform Types}

Pollen types that show little within-basin variation in their frequencies, such as the deciduous tree pollen in southern Michigan lakes, should be most valuable for characterization of regional vegetation. Our data show, for example, that in southern Michigan a single sample is enough to characterize pollen frequencies of regional deciduous trees in each lake. Although there is some variation in sediment in shallow water, the tree pollen frequencies are nevertheless roughly similar everywhere in the lake (Fig. 8). This result means that even small differences in the pollen percentages produced by the vegetation will be detectable, as there is little background noise to mask the true differences. This point is illustrated by the comparison of tree pollen percentages in the seven lakes (Fig. $13 \mathrm{~B}$ ); the percontages of trec pollen arc rcmarkably uniform in nearby lakes. The four eastern lakes
(M, F, W and So), located in an area of farmland, originally mixed-oak forest, are similar to one another. They contain appreciable percentages of pine, ash, beech, maple and hornbeam pollen. The three western lakes ( $\mathrm{P}, \mathrm{B}$, and $\mathrm{Sa})$, located where oak forest has regenerated, have higher oak pollen percentages, reflecting the greater absolute abundance of oak trees in the vicinity.

A chi-square test shows that the deciduous tree pollen assemblages from the seven lakes are nonhomogeneous when considered as a single group $\left(\chi^{2}=45.7, \mathrm{df}\right.$ $=20, p=0.0009$ ). In presettlement time, however, the same test indicates that all six lakes in Washtenaw County were similar in tree pollen content. The percentages of tree pollen in presettlement samples are shown in Fig. 13C. They produce a value of $\chi^{2}=$ $24.02(\mathrm{df}=20, p=0.24)$. This result means the samples are homogeneous by the criterion of a chi-square test (with $20 \mathrm{df}$ ). This similarity in pollen assemblages prevailed, even though we know from land survey records made at that time (Figs. 1 and 2 ) that the forests at the two locations were quite different. Maple, ash, elm, beech and ironwood were much more common in the eastern part of the county than farther west (Merk, 1951). This result implies that pollen dispersal by wind was so effective (even though the landscape was forested) that minor differences in pollen production by the forests were not registered in the lakes. Pollen from lakes such as these studied can be used in this region to record the mean abundance of trees over a very large area. But the pollen seems ineffective in registering minor differences in forest composition over distances measured in tens of kilometers.

Important perspective is added to this conclusion by preliminary results from a similar study of between-lake variation in the Upper Peninsula of Michigan. Here we have found large variations between lakes, related to lake size. The variations involve 
tree pollen, including pine, birch, and oak pollen, although the latter two genera show little or no variation within or between lakes in southern Michigan. The extent to which limnological factors rather than differential input are involved is unclear. But one can say that results from one region should not be applied uncritically to another, where vegetation, pollen flora, and topography are different.

The limnological factors responsible for more or less uniform deposition of tree pollen in southern Michigan, and variable deposition of herb pollen, are the subject of later papers in this series.

\section{ACKNOWLEDGMENTS}

This work has been supported by the National Science Foundation, Grants GB 2377, GB 5320, and GB 7727.

\section{RFFFRFNCFS}

Anonymous. (1881). "History of Washtenaw County, Michigan." Chas. C. Chapman \& Co., Chicago.

Davis, M. B. (1968). Pollen grains in lake sediments: redeposition caused by seasonal water circulation. Science 162, 796-799.

Davis, M. B. Redeposition of pollen grains in lake sediments. Limnology and Oceanography, in press.

Davis, R. B. (1967). Pollen studies of near-surface sediments in Maine lakes. In "Quaternary Paleoecology." (E. J. Cushing and H. E. Wright, Jr., Eds.), pp. 143-173. Yale Press, New Haven.
Davis, R. B., Brewster, L. A., and Sutherland, J. (1969). Variation in pollen spectra within lakes. Pollen et Spores 11, 557-572.

FAEGrT, K., and IverSEN, J. (1964). "Textbook of Pollen Analysis," 2nd ed. Munksgaard, Copenhagen.

Fries, M. (1962). Pollen profiles of late Pleistocene and Recent sediments from Weber Lake, Minnesota. Ecology 43, 295-308.

JANSSEN, C. R. (1966). Recent pollen spectra from the deciduous and coniferous-deciduous forests of northeastern Minnesota: A study in pollen dispersal. Ecology 47, 804-825.

Kabaleine, M. (1970). On formation of pollen spectra and restoration of vegetation (In Russian, English Summary). Ministry of Geology of the USSR, Inst. of Geol. (Vilnius) Trans., Vol. II, 147 p.

MCANDRews, J. (1966). Postglacial history of prairie, savanna and forest in northwestern Minnesota. Torrey Botanical Club Memoir 22, 72 pp.

MERK, J. W. (1951). "Tree Species Distribution on the Basis of the Original Land Survey of Washtenaw County, Michigan." M.S. thesis, University of Michigan.

Phleger, F. B. (1951). Ecology of Foraminifera, northwest Gulf of Mexico: Part 1. Foraminifera distribution. Geological Society of America Memoir 46, 1-88.

Pohr, F. (1937). Die Pollenerzeugung der Windblütler. Beih. Bot. Centralbl. 56 A, 365-470.

Rowley, J. R., and Dahl, A. O. (1956). Modifications in design and use of the Livingstone piston sampler. Ecology 37, 849-851.

TAuBer, H. (1967). Differential poilen dispersion and filtration. In "Quaternary Paleoecology." (E. J. Cushing and H. E. Wright, Jr., Eds.), pp. 131-141. Yale Press, New Haven. 